\title{
Estimation of Variability, Correlation and Path Analysis in Soybean (Glycine max (L.) Merr.) Genotypes at Jimma, South Western Ethiopia
}

\author{
Yechalew Sileshi \\ Ethiopian Institutes of Agricultural Research, Jimma Agricultural Research center
}

\begin{abstract}
Thirty-six soybean genotypes were tested with the aim of to determine the extent of genetic variability, correlation and path analysis among soybean genotypes. The field experiment was conducted during the 2017/2018 main cropping season in Jimma South western Ethiopia. The experimental design was triple lattice. Data were collected on 14 quantitative morphological traits .Analysis of variance showed significant to highly significant differences among genotypes for all of the studied traits. The phenotypic coefficient of variation (PCV) ranged from 8.83 for days to maturity to 39.3 for harvest index; while the genotypic coefficient of variation (GCV) value ranged from 4.7 for seed per pod to 30.22 for biomass per plant. Broad sense heritability value ranged from $5.5 \%$ for seed per pod to $95.9 \%$ for days to flowering. The genotypic correlation analysis exhibited that seed yield had positive and significant association with harvest index and hundred seed weight. Harvest index exerted the maximum positive direct effect followed by biomass and pod per plant on grain yield at genotypic levels, these could be used for selection to improve grain yield.
\end{abstract}

Keywords:- Correlation, Path, Variability, Soybean

DOI: $10.7176 / \mathrm{JNSR} / 9-7-03$

Publication date: April $30^{\text {th }} 2019$

\section{INTRODUCTION}

Soybean (Glycine max (L.) Merr.) is known as golden bean and the most widely grown leguminous crop in the world. It occupies an important position among grain legumes and rich in protein and oil contents'. Estimating the extent of genetic variability is the key step in determining the genetic potential of the crop for future improvement. In Ethiopia, soybean has increasing trends in production and productivity over the last decade. A total of 38,072.7 ha of land were covered by soybean (CSA, 2017) and ranks first in yield per ha ${ }^{-1}$ among pulse and oil and $5^{\text {th }}$ in coverage among oil crops grown in the country. In the year 2017 the national average productivity of soybean was $2.27 \mathrm{t} / \mathrm{ha}(\mathrm{CSA}, 2017)$, which was not close to the potential productivity of the crop, compared to its potential productivity in the research fields, which might reach up to 3 tha $^{-1}$ (Abush, 2012). Currently, soybean is one of the focus subsectors supported by government and non-governmental organization; in the recent years several soybean processing plants have been set up in different parts of the country, which began demanding varieties with high grain nutritional compositions viz., oil and protein.

Therefore, the study includes introduced soybean genotypes which were not studied their genetic variability in the past with the aim of to determine genetic variability, Correlation, heritability, genetic advance among the tested soybean genotypes

\section{MATERIALS AND METHODS}

3.1 The Study Area

The field experiment was conducted at Jimma Agricultural Research Centers. Jimma agricultural research centers are located in Oromia regional state, of South Western Ethiopia. Jimma agricultural research center is located at $12 \mathrm{~km}$ distance from Jimma town $\left(1,754 \mathrm{~m} . \mathrm{s} .1,7^{0} 40^{\prime} \mathrm{N} 36^{\circ} 47^{\prime} \mathrm{E}\right)$. The place has a mean maximum and minimum temperature of 26.3 and $11.6^{\circ} \mathrm{C}$ respectively, Mean annual rainfall of $1,572 \mathrm{~mm}$.

3.3 Experimental Design

The experiment was laid out in $6 \times 6$ triple lattice designs. Each plot had four rows each measuring $4 \mathrm{~m}$ long, with a spacing of $60 \mathrm{~cm}$ between rows and $5 \mathrm{~cm}$ between plants. The distance between plots and between blocks was 0.6 and $1.5 \mathrm{~m}$, respectively. DAP fertilizer with rate of $100 \mathrm{~kg}$ per ha was applied at sowing time and all other recommended agronomic management practices were applied properly. 
Table 4.Description of the soybean genotypes used for this study

\begin{tabular}{|c|c|c|c|c|c|c|c|c|c|}
\hline No & $\begin{array}{l}\text { Name } \\
\text { genotypes }\end{array}$ & of & Source & $\begin{array}{l}\text { Year of } \\
\text { introduction }\end{array}$ & No & $\begin{array}{ll}\begin{array}{l}\text { Name } \\
\text { genotypes }\end{array} & \text { of } \\
\end{array}$ & Source & & $\begin{array}{l}\text { Year of } \\
\text { introduction }\end{array}$ \\
\hline 1. & LD13-00833 & & USA & 2016 & 19 & PI417126 & USA & & 2015 \\
\hline 2. & LD11-10649 & & USA & 2016 & 20 & PI507005 & USA & & 2015 \\
\hline 3. & SA13-3135 & & USA & 2016 & 21 & PI615437 & USA & & 2015 \\
\hline 4. & LD13-08470 & & USA & 2016 & 22 & PI628932 & USA & & 2015 \\
\hline 5. & LD13-03483 & & USA & 2016 & 23 & PI462312 & USA & & 2015 \\
\hline 6. & LD13-08466 & & USA & 2016 & 24 & PI605773 & USA & & 2015 \\
\hline 7. & LD13-06216 & & USA & 2016 & 25 & PI605854B & USA & & 2015 \\
\hline 8. & LD10-10198 & & USA & 2016 & 26 & PI594767A & USA & & 2015 \\
\hline 9. & LD13-07022 & & USA & 2016 & 27 & PI416873B & USA & & 2015 \\
\hline 10. & $\begin{array}{l}\text { F6 LG06-5920 } \\
\text { LG04-6000 }\end{array}$ & & USA & 2016 & 28 & PI567180 & USA & & 2015 \\
\hline 11. & $\begin{array}{l}\text { LG04-4468 } \\
\text { U02-242055 }\end{array}$ & $\mathrm{x}$ & USA & 2016 & 29 & PI423960B & USA & & 2015 \\
\hline 12. & $\begin{array}{l}\text { LG04-5993 } \\
\text { LG04-5196 }\end{array}$ & $\mathrm{x}$ & USA & 2016 & 30 & PI635999 & USA & & 2015 \\
\hline 13. & $\begin{array}{l}\text { F6 LG04-4717 } \\
\text { LG05-4292 }\end{array}$ & & USA & 2016 & 31 & PI605865B & USA & & 2015 \\
\hline 14. & PI200466 & & USA & 2015 & 32 & PI423960A & USA & & 2015 \\
\hline 15. & PI587905 & & USA & 2015 & 33 & Afgat & $\begin{array}{l}\text { Released } \\
\text { varieties } \\
\text { Ethiopia }\end{array}$ & in & 2007 \\
\hline 16. & PI416778 & & USA & 2015 & 34 & Nyala & $\begin{array}{l}\text { Released } \\
\text { varieties } \\
\text { Ethiopia }\end{array}$ & in & 2014 \\
\hline 17. & PI459025B & & USA & 2015 & 35 & Nova & $\begin{array}{l}\text { Released } \\
\text { varieties } \\
\text { Ethiopia }\end{array}$ & in & 2012 \\
\hline 18 & PI594149 & & USA & 2015 & 36 & Clark $63 \mathrm{~K}$ & $\begin{array}{l}\text { Released } \\
\text { varieties } \\
\text { Ethiopia }\end{array}$ & in & 1981 \\
\hline
\end{tabular}

3.4 Data Collection

The following quantitative data were collected on plot or plant base.

Days to flowering (DF) (days): Days to 50\% flowering was taken from number of days from sowing to when 50\% of plants in a plot open flower.

Days to maturity (DM) (days):-Number of days from planting to when $95 \%$ of the Plants in a plot change the color of their pod from green to lemon yellow.

Hundred Seed Weight (HSW) (gm): Weight of 100 seeds was determined by weighting the mass of 100 seeds. Plant height (PH) (cm): The length of plant wasmeasured from the soil surface up to the tip of the main stem on randomly selected five plants and was taken the mean at each plot.

Number of trifoliate leaf per plant (count):- Average number oftrifoliate leaf was taken by counting the number trifoliate leaf on randomly selected five plants and was taken the mean at each plot at (R5) seed filing stage.

Number of pods per plant (count): The average number of pods, counted at harvest on 5 randomly selected plants.

Pod length (PL) (cm): Average length of pods, measured at physiological maturity on 5 randomly selected plants and five randomly taken pods per plant.

Pod diameter ( inch).Pod diameter was taken, at physiological maturity on 5 randomly

Biological Yield (BY) (gm): The above ground parts of the plants were oven dried and averaged over the 5 sample plants to get the biological yield per plant in grams.

Harvest Index (HI)(ratio): The harvest index was estimated by dividing total seed yield by biological yield on 5 sample plant.

Number of seeds per pod (SPP) (count): The number of seeds per pod, counted at harvest on 5 randomly selected plants.

Internodes length (cm): Internodes length was measured as the distance between two nodes at the mid, bottom and top part of the plant from 5 randomly selected plants per plot by using ruler and was taken the average of all 5 plants.

Seed yield per plot (SYP) (gm): seed yield in grams, harvested from plants in the two central rows measured in 
gram.

Internodes length (cm): Internodes length was measured as the distance between two nodes at the mid, bottom and top part of the plant from 5 randomly selected plants per plot by using ruler and was taken the average of all 5 plants.

\section{Statistical Data Analyses}

Analyses of variance

Before conducting statistical analysis, data were checked for the normality and all the data meet the assumption. The data collected for each quantitative trait was subjected to analysis of variance (ANOVA) as per the method of Gomez and Gomez (1984) using Proc lattice and Proc GLM procedures of SAS computer Software program (SAS, 2002, Version 9.0) to assess the significant of the difference between the accessions. Least Significant Difference (LSD) at $\mathrm{p}<0.05$ were employed to identify genotypes that are significantly different from each other. The ANOVA model and structure for triple lattice design indicated as follows:

Yil $(j)=\mu+$ gi + rj $+(b / r) l(j)+$ eil $(j)$ Where, Yil (j) is the response the trait $Y$ in the $i^{\text {th }}$ genotype, in the $1^{\text {th }}$ block of the $\mathrm{j}^{\text {th }}$ replication; $\mu$ is grand mean of the trait $Y$, gi is the effect of $i^{\text {th }}$ genotype, rj is the effect of $j^{\text {th }}$ replication, (b/r) $1(\mathrm{j})$ is the effect of $\mathrm{l}^{\text {th }}$ block of the $\mathrm{j}^{\text {th }}$ the replication, $\mathrm{il}(\mathrm{j}) e$ is the error associated to the observation Yil (j), Table 5. Skeleton of Analysis of variance (ANOVA) for simple lattice design (single location)

\begin{tabular}{llll}
\hline Sources of variation & $\mathrm{Df}$ & $\mathrm{SS}$ & $\mathrm{MS}$ \\
\hline Replication & $\mathrm{R}-1$ & $\mathrm{SS}_{\mathrm{R}}$ & $\mathrm{MS}_{\mathrm{R}}$ \\
Block (adjusted) & $\mathrm{R}(\mathrm{k}-1)$ & $\mathrm{SS}_{\mathrm{B}}$ & $\mathrm{MS}_{\mathrm{B}}$ \\
Genotype (adjusted) & $\left(\mathrm{G}^{2}-1\right)$ & $\mathrm{SS}_{\mathrm{GAdj}}$ & $\mathrm{MS}_{\mathrm{G}}$ \\
Genotypes unadjusted & $\left(\mathrm{G}^{2}-1\right)$ & $\mathrm{SS}_{\mathrm{GU}}$ & $\mathrm{MS}_{\mathrm{GU}}$ \\
Intra-block( error) & $(\mathrm{k}-1)(\mathrm{Rk}-\mathrm{k}-1)$ & $\mathrm{SS}_{\mathrm{E}}$ & $\mathrm{MS}_{\mathrm{E}}$ \\
Total & $(\mathrm{R})\left(\mathrm{k}^{2}\right)-1$ & $\mathrm{SS}_{\mathrm{T}}$ & \\
\hline
\end{tabular}

Where, $\mathrm{R}=$ number of replication, $\mathrm{G}=$ number of genotypes, $\mathrm{Df}=$ degree of freedom, $\mathrm{B}=\mathrm{block}, \mathrm{SS}=\mathrm{Sum}$ of squares, MS = mean squares, SSR and MSR are sums of squares and mean of replication, respectively; SSG and MSG are sums of squares and mean of genotypes, respectively; SSB and MSB are sums of squares and mean of blocks within replication respectively, SSE and MSE are sums of squares and mean of intra-block error, respectively and SST is sum of squares of the total.

3.5.2 Estimation of phenotypic and genotypic variances

The phenotypic and genotypic variances of each trait were estimated from the analysis of variance, as per the methods suggested by Burton and Devane (1953).then by using the methods suggested by Dewey and Lu, (1959) phenotypic and genotypic coefficient of variation was calculated as follows:

Phenotypic coefficient of variation $(\mathrm{PCV})=\frac{\sqrt{\sigma 2 p}}{\overline{\mathrm{x}}} \mathrm{x} 100$

Genotypic coefficient of variation $(\mathrm{PCV})=\frac{\sqrt{\sigma 2 \mathrm{~g}}}{\overline{\mathrm{x}}} \mathrm{x} 100$

Where: $\sigma^{2} \mathrm{p}=$ Phenotypic variation; $\sigma^{2} \mathrm{~g}=$ Genotypic variation and $\overline{\mathrm{x}}=$ Grand mean of the trait under consideration. According to Sivasubramanian and Menon, (1973) PCV and GCV values more than $20 \%$ are regarded as high, whereas values less than $10 \%$ are considered to be low and values between 10 and $20 \%$ to be moderate.

3.5.3. Estimation of heritability

3.5.3.1 Heritability in broad sense

Heritability in broad sense estimates the ratio of total genetic variance, including additive, dominance, and epistatic variance, to the phenotypic variance (Raiz and Chowdhry, 2003) $H=\frac{\delta^{2} g}{\delta^{2} p} x 100$. . Where, H= heritability in the broad sense. $\left(\delta^{2} g\right)=$ Genotypic variance and $\left(\delta^{2} p\right)=$ Phenotypic variance.

3.5.4 Expected genetic advance (GA)

Genetic advance (GA) and percent of the mean (GAM) were calculated by

Assuming selection of superior $5 \%$ of the genotypes estimated in accordance with the methods illustrated by

Johnson et al. (1955) as $G A=K * \delta_{P} * H$

Where, $\mathrm{GA}=$ expected genetic advance, $\delta_{p}=$ phenotypic standard deviation on mean basis, $\mathrm{H}=$ Heritability in broad sense, $\mathrm{K}=$ selection differential (where $\mathrm{k}=2.06$ at $5 \%$ selection intensity)

Genetic advance (as percent of mean) (GA) was computed to compare the extent of predicted genetic advance of different traits under selection, using the formula: 


$$
G A M=\frac{G A}{\bar{X}} * 100
$$

Where, $\bar{x}=$ population mean of the quantitative character, $\mathrm{GA}=$ genetic advance as percent of mean 3.5.5 Analysis of genotypic and phenotypic coefficient of correlation

Phenotypic correlation (rp), the observable correlation between two variables, which includes both genotypes and environmental components between two variables, were estimated using the formula suggested by Johnson et al(1955) and Singh and Chaudhury (1985).

$\mathrm{rp}_{\mathrm{xy}}=\operatorname{pcov}(\mathrm{x}, \mathrm{y}) / \sqrt{ }\left(\sigma^{2} \mathrm{px} * \sigma^{2} \mathrm{py}\right)$,

$\mathrm{rg}_{\mathrm{xy}}=\operatorname{gcov}(\mathrm{x}, \mathrm{y}) / \sqrt{ }\left(\sigma^{2} \mathrm{gx} * \sigma^{2} \mathrm{~g}\right.$ y)Where, $\mathrm{rp}_{\mathrm{xy}}$ and $\mathrm{rg}_{\mathrm{xy}}$ are phenotypic and genotypic correlation coefficients, respectively; pcovxyand gcovxy are phenotypic and genotypic covariance between variables $\mathrm{x}$ and $\mathrm{y}$, respectively; $\sigma^{2} \mathrm{px}$ and $\sigma^{2} \mathrm{gx}$ are phenotypic and genotypic, variances for variable $\mathrm{x}$; and $\sigma^{2} \mathrm{py}$ and $\sigma^{2} \mathrm{~g}$ y are phenotypic and genotypic variances for the variable $y$, respectively.

The calculated phenotypic correlation value was tested for its significant using t-test:

$\mathrm{t}=\mathrm{r}_{\mathrm{ph}} / \mathrm{SE}\left(\mathrm{r}_{\mathrm{ph}}\right)$ Where, $\mathrm{r}_{\mathrm{ph}}=$ Phenotypic correlation; $\mathrm{SE}\left(\mathrm{r}_{\mathrm{ph}}\right)=$ Standard error of phenotypic correlation was obtained using the following formula (Sharma, 1998).

$\mathrm{SE}\left(\mathrm{r}_{\mathrm{ph}}\right)=\sqrt{ }\left(1-\mathrm{r}_{\mathrm{ph}}^{2}\right) /(\mathrm{n}-2)$ Where, $\mathrm{n}$ is the number of genotypes tested, $\mathrm{r}_{\mathrm{ph}}$ is phenotypic correlation coefficient. The coefficient of correlation at genotypic levels was tested for their significant by the formula de-scribed by Robertson (1959) as indicated below: $t=\mathrm{rg}_{\mathrm{xy}} /$ SErgxy. The calculated " $\mathrm{t}$ " value was compared with the tabulated " $\mathrm{t}$ " value at (n-2) degree of freedom at $5 \%$ level of significant. Where, $\mathrm{n}$ is number of genotypes.

$\mathrm{SEr}_{\mathrm{gxy}}=\sqrt{ }(1-\mathrm{r} 2 \mathrm{gxy}) / 2 \mathrm{~h}^{2} \mathrm{x} \cdot \mathrm{h}^{2} \mathrm{y} ;$ Where, $\mathrm{h}^{2} \mathrm{x}=$ heritability of trait $\mathrm{x} ; \mathrm{h}^{2} \mathrm{y}=$ heritability of trait $\mathrm{y}$.

3.5.6. Path coefficient analysis

The direct and indirect effect of yield related traits on yield per plot was worked out through path coefficient analysis. The analysis was made following the method suggested by Dewey and Lu (1959). The formula was described as follows. $\mathrm{r}_{\mathrm{ij}}=\mathrm{P}_{\mathrm{ij}}+\Sigma \mathrm{r}_{\mathrm{ik}} \mathrm{p}_{\mathrm{kj}}$ Where: - rij = Mutual association between the independent trait (i) and dependent trait (j) as measured by the correlation coefficient. $\mathrm{Pij}=$ Component of direct effects of the independent trait (i) on the dependent variable (j) as measured by the path coefficient and, $\Sigma$ rikpkj = Summation of components of indirect effect of a given independent trait (i) on the given dependent trait (j) via all other independent traits $(\mathrm{k})$. Residual effect estimated by the formula $\sqrt{ } 1-R^{2}$; Where: $-R^{2}=\Sigma$ pijrijWhere, $R^{2}$ is the residual factor, Pij is the direct effect of yield by $\mathrm{i}^{\text {th }}$ trait, and rij is theCorrelation of yield with the $\mathrm{i}^{\text {th }}$ trait of variables considered as indicated by (Singh and Chaudhary, 1985).

\section{RESULTS AND DISCUSSION}

Analysis of variance (ANOVA) indicated significant to highly significant $(\mathrm{P}<0.05$ and 0.01$)$ differences among genotypes for all of the studied traits (Table1), this indicates the presence of considerable genetic variability among the tested soybean genotypes for various characters suggested that the genotypes were genetically diverse and could be a good opportunity for breeders to select genotypes for trait of interest.

Table1. Analysis of variance summary for yield and related traits at Jimma in 2017/2018

\begin{tabular}{|l|l|l|l|l|l|l|l|l|}
\hline \multicolumn{2}{|c|}{} & \multicolumn{9}{c|}{ Mean square } & \multicolumn{2}{c|}{ Error } & \\
\hline Traits & Replication & Un adj & Adj & $\begin{array}{l}\text { Blocks } \\
\text { with in } \\
\text { rep(Adj) }\end{array}$ & Intra & RCBD & $\begin{array}{l}\text { RE } \\
\text { RCBD(\%) }\end{array}$ & CV \\
\hline FD & 3.11 & 295.10 & $231.20^{* *}$ & 4.92 & 3.28 & 4.92 & 106 & 3.25 \\
\hline MD & 123.58 & 3202.00 & $269.60^{* *}$ & 88.21 & 52.60 & 88.21 & 105.37 & 5.70 \\
\hline NT & 35.30 & 76.65 & $70.17^{* *}$ & 8.68 & 14.00 & 8.68 & 91.54 & 19.80 \\
\hline PH(cm) & 569.33 & 867.50 & $715.76^{* *}$ & 37.24 & 38.79 & 37.24 & 99.14 & 10.06 \\
\hline IL(cm) & 1.59 & 2.40 & $2.14^{* *}$ & 0.50 & 0.66 & 0.50 & 94.56 & 16.90 \\
\hline PP & 1.42 & 76.60 & $66.51^{* *}$ & 4.37 & 5.27 & 4.37 & 96.34 & 8.40 \\
\hline PL(cm) & 0.21 & 0.48 & $0.39^{* *}$ & 0.15 & 0.14 & 0.15 & 100.14 & 11.00 \\
\hline PW(inc) & 0.00 & 0.00 & $0.00^{* *}$ & 0.00 & 0.00 & 0.00 & 102.50 & 11.08 \\
\hline SP & 215.13 & 279.95 & $265.90^{* *}$ & 101.44 & 63.99 & 101.44 & 104.00 & 17.38 \\
\hline SPD & 0.13 & 0.13 & $0.13 n$ & 0.14 & 0.11 & 0.14 & 101.28 & 19.40 \\
\hline BY(g) & 1.21 & 113.16 & $92.46^{* *}$ & 1.66 & 1.90 & 1.66 & 97.15 & 7.62 \\
\hline HI & 0.02 & 0.04 & $0.03^{*}$ & 0.02 & 0.02 & 0.02 & 100.03 & 34.00 \\
\hline HW(g) & 1.41 & 36.98 & $28.96^{* *}$ & 4.07 & 3.04 & 4.07 & 101.73 & 9.40 \\
\hline Yield & 0.08 & 52.89 & $45.44^{* *}$ & 2.21 & 2.08 & 2.21 & 100.07 & 8.05 \\
\hline
\end{tabular}




\subsubsection{Range and Mean of Parameters}

Wide ranges between the minimum and maximal mean values were observed for the 14 traits evaluated for the tested genotypes (Table 2). In the present investigation for days to $50 \%$ flowering recorded to shortest (42 days) for the genotypes LD10-10198 while genotypes PI635999recorded the most delayed flowering (73 days), with mean vale of 55.6 days, days to maturity ranges from 106-141 days for the genotypes PI615437 and PI416873B respectively with mean value of 126.5 days, Similar trends of variability in days to maturity in different genotypes have been reported by Adiyataet al. (2011). While number of trifoliate leaf maximum for genotypes PI594767A (34) and minimum for genotypes LD10-10198 (13.5) the maximum plant height recorded in the genotypes PI635999 $(91.7 \mathrm{~cm})$ while the minimum plant height was observed in the genotypesLD13-03483 $(35.7 \mathrm{~cm})$ with mean value of $61.9 \mathrm{~cm}$. Singh (2009) reported a range of $66.25-110.75 \mathrm{~cm}$ for plants height. The maximum and minimum internode length were recorded on the genotypes PI462312 (6.3) andPI416778 (3.3) respectively, with mean value of $4.8 \mathrm{~cm}$ the maximum no of pod per plant was recorded on the genotypes LD11-10649(40.9) while the minimum was observed PI567180(17),GenotpesPI459025(4.3) observed maximum for pod length while the minimum was observed on the genotypes PI594767A(2.8) The maximum pod width was observed on the genotypes PI459025B(0.4) and the lowest on the genotypes PI594149(0.2)

Maximum and minimum Seed per pod were recorded on the genotypes Nova (73.5) and PI416778 (28.3) respectively, the maximum seed per pod was observed on the genotypes PI567180 (2.3) while the minimum was observed on the genotype PI416778 (1.1), biomass per plant from37.9g for genotype LD13-08466to 9.7g for genotype PI635999; harvest index from 0.67 for a genotype PI594767A to 0.2 for a genotype PI416778, and hundred seed weight from $28.6 \mathrm{~g}$ for a genotype PI594149to $12.3 \mathrm{~g}$ for a genotype Nova. Similar result was reported by Shankar (2014), Yield ranged from8.4-28.9 tha ${ }^{-1}$ for the genotypes PI416778 and PI587905 respectively;

\section{Estimation of variability components}

The estimated phenotypic coefficient of variation (PCV) and genotypic (GCV) coefficients of variations are presented in (Table 3). The GCV ranged from $4.73 \%$ for seed per pod to $30.2 \%$ biomass and PCV from $8.83 \%$ for days to maturity to $39.36 \%$ for harvest index. The GCV and PCV values were categorized as low $(<10 \%)$, moderate (10 to $20 \%)$ and high $(>20 \%)$ as indicated by Deshmukh et al. (1986). Based on this categorization high PCV and GCV values were found for number of trifoliate leaves per plant(21.85 and 28.89), plant height(24.28 and 26.28), biomass(30.22 and31.16) and grain yield (21.33 and 22.8) (Table). Similar results were reported by Yadav et al. (2015) for plant height. The result shows that the variability among genotypes for these characters was mainly due to genetic effects than that of environment. Therefore, selection for these characters based on phenotypic appearance would likely result in improvement. Medium GCV and PCV was observed for days to flowering (15.68 and 16.01\%), hundred seed weight (15.7 and18.44) and pod per plant (16.6 and 18.63\%), respectively. Similarly, moderate PCV and GCV values were reported for days to $50 \%$ flowering (Wanderi et al., 2013) and (Agdew et al.,2012). This indicated that the genotype could be reflected by the phenotype and the effectiveness of selection based on the phenotypic performance for these characters. Low PCV and GCV values were found for days to maturity (Table 2 ); showing narrow range of variability, suggesting the limited scope for improvement of these traits through selection so creating variability is the first step.The obtained results are in agreement with results reported by (Deresse, 2017)

\section{Estimation of heritability and expected genetic advance}

The heritability estimates ranged from $5.5 \%$ for seed per pod to $95.8 \%$ for days to flowering. According to Singh (1990), for a trait with high heritability $(\geq 80 \%)$, selection is reasonably easy, due to smaller contribution of environment to genetic. High heritability was observed for plant height, yield $(85 \%)$, and biomass per plant (94\%).This implies the variation observed was mainly under genetic control and was less influenced by the environment and the possibility of progress from selection. The obtained results are in agreement with results reported by Ramtekeet al. (2010) for plant height and biomass per plant. Moderate heritability values (40-80\%) were observed for days to maturity, number of trifoliate leaves, internode length, pod per plant, pod width, seed per pod and hundred seed weight. Similar results were reported by other workers (Zinawet al., 2013 and Reni et al., 2013). Low heritability values were observed for yield per ha- ${ }^{1}$ ( Low heritability $(<40)$ estimated were observed for pod length, harvest index and seed per pod indicated that narrow genetic base for this traits. Selection for these characters would not be effective due to the predominant effects of non- additive genes. It has been suggested that heritability estimates together with genetic advance are more helpful in predicting the gain under selection than heritability estimates alone in selecting best individuals because heritability does not provide indication of amount of genetic progress that would result from selecting the best individuals (Johnson et al., 1955). High heritability is coupled with high genetic advance as percent of mean observed for days to flowering, days to maturity, plant height, biomass and grain yield. This show that the heritability of these characters is due to additive gene effects, and selection might be effective for these characters ( Rahman et al., 2016). 
Table 2.Means, ranges, phenotypic and genetic variability, heritability, genetic advance and genetic gains estimates for soybean traits over three locations in 2017/2018 main cropping season

\begin{tabular}{|l|l|l|l|l|l|l|l|l|l|}
\hline Traits & Ranges & Mean & $\boldsymbol{\sigma}^{\mathbf{2}}$ & $\boldsymbol{\sigma}^{\mathbf{2}} \mathbf{p}$ & $\mathbf{P C V} \mathbf{0}$ & $\mathbf{G C V} \%$ & $\left.\mathbf{h}^{\mathbf{2}} \mathbf{b} \mathbf{\%}\right)$ & $\mathbf{G A}$ & $\mathbf{G A M} \mathbf{( \% )}$ \\
\hline FD(days) & $42-73$ & 55.6 & 75.97 & 79.25 & 16.01 & 15.68 & 95.86 & 17.58 & 31.62 \\
\hline MD(days) & $106-141.5$ & 126.5 & 72.33 & 124.9 & 8.83 & 6.72 & 57.90 & 13.33 & 10.54 \\
\hline NT(count) & $13.5-34$ & 19.8 & 18.72 & 32.72 & 28.89 & 21.85 & 57.22 & 6.74 & 34.05 \\
\hline PH(cm) & $35.7-91.7$ & 61.9 & 225.6 & 264.5 & 26.28 & 24.28 & 85.33 & 28.59 & 46.20 \\
\hline IL(cm) & $3.3-6.3$ & 4.8 & 0.49 & 1.15 & 22.29 & 14.58 & 42.77 & 0.95 & 19.65 \\
\hline PP(count) & $17.0-40.9$ & 27.2 & 20.41 & 25.68 & 18.63 & 16.60 & 79.48 & 8.30 & 30.49 \\
\hline PL(cm) & $2.8-4.3$ & 3.4 & 0.08 & 0.22 & 14.02 & 8.63 & 37.92 & 0.37 & 10.95 \\
\hline PW(inch) & $0.2-0.4$ & 0.3 & 0.00 & 0.00 & 15.08 & 10.20 & 45.75 & 0.04 & 14.22 \\
\hline SP(count) & $28.7-73.5$ & 46.0 & 67.30 & 131.3 & 24.90 & 17.83 & 51.26 & 12.10 & 26.30 \\
\hline SPD(count) & $1.1-2.3$ & 1.7 & 0.01 & 0.12 & 20.13 & 4.73 & 5.52 & 0.04 & 2.29 \\
\hline BY(g) & $9.7-37.9$ & 18.2 & 30.19 & 32.09 & 31.16 & 30.22 & 94.08 & 10.98 & 60.38 \\
\hline HI & $0.2-0.7$ & 0.4 & 0.00 & 0.02 & 39.36 & 17.28 & 19.28 & 0.06 & 15.63 \\
\hline HW(g) & $12.3-28.6$ & 18.5 & 8.64 & 11.68 & 18.44 & 15.86 & 73.94 & 5.21 & 28.09 \\
\hline Yield(q) & $8.4-28.9$ & 17.8 & 14.45 & 16.53 & 22.82 & 21.33 & 87.42 & 7.32 & 41.09 \\
\hline
\end{tabular}

Where $; \mathrm{DF}=$ days to flowering, $\mathrm{MD}=$ days to $\%$ maturity, $\mathrm{NT}=$ number of trifoliate leaf, $\mathrm{PH}=$ plant height, $\mathrm{IL}=$ internodes length, $\mathrm{PP}=$ pod per plant, $\mathrm{PL}=$ pod length, $\mathrm{PW}=$ pod width, $\mathrm{SP}=$ seed per plant, $\mathrm{SPD}=$ seed per pod ,BY= biological yield ,HI=harvest index, $\mathrm{HW}=$ hundred seed weight

Correlation among yield and yield related trait.

Days to $50 \%$ flowerings was correlated positively and significantly with days to maturity, number of trifoliate leaves, plant height, internodes length, pod per plant, pod length and biomass: while negatively and significantly correlated with harvest index at both phenotypic and genotypic levels. Similar results were reported in which days to $50 \%$ flowering correlated positively and significantly with days to maturity, plant height and number of branches (Preeti, 2018). Grain yield had positive and highly significant $(\mathrm{P}<0.01)$ genotypic correlation with hundred seed weight $(0.25)$ similarly grain yield also exhibited positive and significant $(\mathrm{P}<0.05)$ genotypic correlation with harvest index (0.51) (Table 3), the positive correlation of these characters with grain yield resulted from the presence of strong linkage of genes or the characters might be the result of pleiotropic genes that control these characters in the same direction. Such association is important for simultaneous improvement of two traits.

Table 3. Estimation of genotypic (above diagonal) and phenotypic (below diagonal) correlation coefficient for 14 morphological traits in 36soybean genotypes

\begin{tabular}{|c|c|c|c|c|c|c|c|c|c|c|c|c|c|c|}
\hline Traits & FD & MD & NIT & $\mathrm{PH}$ & NL & PP & PL & $\mathrm{PW}$ & SP & SPD & BOI & $\mathrm{HI}$ & $\mathrm{HW}$ & Yield \\
\hline FD & 1.00 & $0.74^{* *}$ & $0.72 * *$ & $0.87 * *$ & $0.62^{* *}$ & $0.44^{* *}$ & $0.37^{*}$ & -0.20 & $0.35^{*}$ & -0.05 & $0.54^{* *}$ & $-0.40^{*}$ & -0.30 & 0.00 \\
\hline $\mathrm{MD}$ & $0.61^{* *}$ & 1.00 & $0.55^{* * *}$ & $0.64 * *$ & $0.48^{* *}$ & 0.30 & 0.25 & 0.03 & 0.16 & -0.14 & $0.59^{* *}$ & $-0.53 * *$ & -0.08 & -0.08 \\
\hline NIT & $0.60^{* *}$ & $0.39^{* *}$ & 1.00 & $0.68^{* *}$ & $0.38^{*}$ & $0.52^{* *}$ & 0.25 & -0.29 & $0.47 * *$ & 0.01 & 0.26 & -0.27 & $-0.43^{* *}$ & 0.12 \\
\hline $\mathrm{PH}$ & $0.81^{* *}$ & $0.52^{* *}$ & $0.60^{* * *}$ & 1.00 & $0.80^{* *}$ & $0.45^{* *}$ & $0.50^{* * *}$ & -0.31 & $0.43^{* *}$ & 0.07 & $0.54^{* *}$ & $-0.36^{*}$ & $-0.36^{*}$ & 0.00 \\
\hline NL & $0.49^{* *}$ & $0.32^{* *}$ & $0.27^{* *}$ & $0.66^{* *}$ & 1.00 & 0.31 & 0.31 & -0.28 & 0.28 & 0.04 & $0.44^{* *}$ & -0.29 & -0.25 & 0.05 \\
\hline $\mathrm{PP}$ & $0.41^{* *}$ & $0.22^{*}$ & $0.38^{* * *}$ & $0.37 * *$ & $0.19^{*}$ & 1.00 & 0.06 & $-0.42^{*}$ & $0.84^{* *}$ & -0.16 & 0.21 & -0.09 & $-0.44^{* *}$ & 0.14 \\
\hline PL & $0.31^{* *}$ & $0.17^{* *}$ & 0.13 & $0.37 * *$ & $0.19^{*}$ & 0.05 & 1.00 & 0.23 & $0.16^{* * *}$ & 0.18 & $0.37^{* *}$ & -0.31 & 0.18 & 0.00 \\
\hline PW & -0.15 & 0.11 & $-0.24^{*}$ & $-0.23^{*}$ & -0.18 & $-0.30^{* * *}$ & $0.22^{*}$ & 1.00 & $-0.48 * *$ & -0.21 & 0.29 & -0.23 & $0.84^{* * *}$ & 0.18 \\
\hline SP & $0.27^{* *}$ & 0.11 & $0.30^{* * *}$ & $0.33^{* *}$ & 0.19 & $0.62^{* *}$ & 0.18 & $-0.29 * *$ & 1.00 & $0.39 *$ & 0.11 & 0.09 & $-0.51^{* *}$ & 0.27 \\
\hline SPD & -0.03 & -0.07 & 0.01 & 0.07 & 0.06 & $-0.21^{*}$ & 0.18 & -0.09 & $0.62^{* *}$ & 1.00 & -0.15 & 0.25 & -0.23 & 0.21 \\
\hline BOI & $0.52^{* *}$ & $0.51^{* *}$ & $0.23 * *$ & $0.51 * *$ & $0.36^{* *}$ & $0.20^{*}$ & $0.28 * *$ & $0.23 *$ & 0.09 & -0.09 & 1.00 & $-0.67 * *$ & $0.34 * *$ & 0.19 \\
\hline $\mathrm{HI}$ & $-0.27 * *$ & $-0.37^{* * *}$ & $-0.20^{*}$ & $-0.27 * *$ & $-0.20^{*}$ & -0.04 & -0.16 & -0.11 & 0.10 & $0.15^{*}$ & $-0.50 * *$ & 1.00 & -0.16 & $0.34^{*}$ \\
\hline $\mathrm{HW}$ & $-0.29^{*}$ & -0.04 & $-0.30^{* *}$ & $-0.33^{* *}$ & $-0.21 *$ & $-0.38^{* *}$ & 0.13 & $0.63^{* *}$ & $-0.34 * *$ & -0.07 & $0.31^{* *}$ & -0.10 & 1.00 & $0.25^{* *}$ \\
\hline Yield & 0.00 & -0.07 & 0.11 & 0.00 & -0.01 & 0.12 & -0.03 & 0.12 & $0.22 *$ & $0.14^{*}$ & 0.18 & $0.22 *$ & $0.23^{*}$ & 1.00 \\
\hline
\end{tabular}

4.1.7.1Genotypic path coefficient analysis

Genotypic path coefficient analysis indicated that harvest index (0.74) showed the maximum positive direct effect (0.79) on seed yield, the positive direct effect of pods per plant with grain yield was assisted by plant height, internodes length, and pod length. These results are in-conformity with that of Malik et al. (2007); Yadav et al. (2009) and Sultana et al. (2005). The number pods per plants showed the highest positive indirect effect on seed yield via seed per plant (0.712). However, the second negative indirect effects were also recorded for this trait via pod width $(-0.433)$.

The second maximum positive direct effect was observed for biomass (0.66) on seed yield. The positive indirect effect was manifested via number of nodes, internodes length, and pod per plant, pod length, seed per pod, harvest index, dry root weight, root length, leaf length and oil. Plant height showed the second highest positive indirect effect on seed yield via day to $50 \%$ flowering (0.6). However, the third negative indirect effects were also recorded for this trait via harvest index $(-0.43)$. These results of positive direct effect on seed yield are in agreement with the reports of Sultana et al. (2005), Malik et al. (2007), and Yadav et al. (2009). The third maximum positive direct effect was observed on pod per plant $(0.44)$ on seed yield. the positive direct effect of pod length with grain yield was assisted through plant height, number of nodes, internodes length, pod per plant, seed per pod, harvest index, hundred seed weight, dry root weight, root length, nodule number, leaf length, protein, and oil content. The 
character that exerted the highest negative genotypic direct effect on seed yield were recorded for plant height, ($0.36)$ days to maturity $(-0.18)$, followed by pod length $(-0.13)$

Table 4.Estimates of direct (bold and diagonal) and indirect effect (off diagonal) of different traits on grain yield at genotypic level in 36 soybean genotypes at Jimma

\begin{tabular}{|c|c|c|c|c|c|c|c|c|c|c|c|c|c|c|}
\hline Traits & FD & MD & SNIT & SPH & SNL & SPP & SPL & SPW & SP & SPOD & BOI & $\mathrm{HI}$ & HW & $\mathrm{rp}$ \\
\hline FD & 0.055 & -0.137 & 0.221 & -0.316 & 0.166 & 0.196 & -0.048 & -0.050 & -0.068 & -0.017 & 0.353 & -0.295 & -0.061 & -0.001 \\
\hline MD & 0.041 & -0.184 & 0.168 & -0.232 & 0.129 & 0.133 & -0.032 & 0.007 & -0.032 & -0.054 & 0.386 & -0.393 & -0.017 & -0.080 \\
\hline SNIT & 0.040 & 0.000 & 0.306 & -0.249 & 0.103 & 0.230 & -0.032 & -0.072 & -0.092 & 0.004 & 0.173 & -0.200 & -0.087 & 0.123 \\
\hline SPH & 0.047 & -0.117 & 0.209 & -0.365 & 0.215 & 0.199 & -0.064 & -0.079 & -0.083 & 0.028 & 0.352 & -0.270 & -0.074 & -0.001 \\
\hline SNL & 0.034 & -0.088 & 0.117 & -0.291 & 0.269 & 0.137 & -0.040 & -0.070 & -0.054 & 0.016 & 0.289 & -0.218 & -0.051 & 0.048 \\
\hline SPP & 0.024 & -0.055 & 0.158 & -0.163 & 0.082 & 0.446 & -0.007 & -0.105 & -0.163 & -0.060 & 0.137 & -0.064 & -0.089 & 0.142 \\
\hline SPL & 0.020 & -0.046 & 0.075 & -0.181 & 0.084 & 0.026 & -0.129 & 0.059 & -0.030 & 0.067 & 0.246 & -0.232 & 0.037 & -0.004 \\
\hline SPW & -0.011 & -0.005 & -0.088 & 0.115 & -0.075 & -0.186 & -0.030 & 0.251 & 0.094 & -0.078 & 0.193 & -0.168 & 0.172 & 0.183 \\
\hline SP & 0.019 & -0.030 & 0.144 & -0.156 & 0.074 & 0.373 & -0.020 & -0.122 & -0.195 & 0.148 & 0.075 & 0.063 & -0.104 & 0.270 \\
\hline SPOD & -0.003 & 26 & 0.003 & -0 . & 0.011 & -0.071 & -0.023 & -0.052 & & 0.376 & -0.097 & 0.185 & -0.047 & 0.206 \\
\hline BOI & 0.029 & -0.108 & 0.081 & -0.196 & 0.119 & 0.093 & -0.048 & 0.074 & -0.022 & -0.055 & 0.656 & -0.498 & 0.070 & 0.193 \\
\hline $\mathrm{HI}$ & -0.022 & 0.097 & -0.083 & 0.133 & -0.079 & -0.039 & 0.040 & -0.057 & -0.017 & 0.094 & -0.440 & 0.742 & -0.033 & 0.337 \\
\hline HW & -0.016 & 0.015 & -0.132 & 0.132 & -0.068 & -0.194 & -0.023 & 0.212 & 0.099 & -0.086 & 0.225 & -0.120 & 0.203 & 0.246 \\
\hline
\end{tabular}

\section{Conclusion}

The study result indicated the presence of adequate genetic variability among the soybean genotypes which can be exploited to develop high yielding varieties. Moderate GCV coupled with moderate PCV (10 to $20 \%$ ) was observed for the number of trifoliate leaves per plant, plant height, biomass and grain yield, this indicating the effectiveness of selection based on the phenotypic performance of the genotypes. High heritability $(>80 \%)$ coupled with moderate genetic advance as percent of mean (10 to $20 \%)$ was observed for plant height, yield and biomass per plant (94\%). This implies that the variation observed was mainly under genetic control and the possibility of progress from selection. Grain yield had positive and highly significant correlation with biomass and harvest index. This suggested that, grain yield potential can be effectively improved by obtaining maximum expression of these characters

\section{CONFLICT OF INTEREST}

The author declares no conflicts of interests.

\section{ACKNOWLEDGEMENT}

Thank the Ethiopian institutes of agricultural research and soybean innovation laboratory (SIL) for the financial support.

Table 5.Appindex Mean performance of genotypes at Jimma 2017/2018

\begin{tabular}{|c|c|c|c|c|c|c|c|c|c|c|c|c|c|c|}
\hline Genotypes & DF & MD & NIT & $\mathrm{PH}$ & $\mathrm{NL}$ & $\mathrm{PP}$ & PL & PW & SP & SPD & $\mathrm{BO}$ & $\mathrm{HI}$ & HW & YQ \\
\hline LD13-00833 & 44.00 & 112.35 & 15.00 & 44.13 & 4.43 & 28.93 & 2.87 & 0.30 & 39.27 & 1.40 & 10.10 & 0.50 & 18.03 & 17.17 \\
\hline LD11-10649 & 61.00 & 127.13 & 25.40 & 66.33 & 4.63 & 40.90 & 3.83 & 0.23 & 67.33 & 1.67 & 15.37 & 0.37 & 14.23 & 15.13 \\
\hline SA13-3135 & 55.67 & 123.22 & 18.40 & 41.00 & 3.73 & 28.27 & 2.97 & 0.30 & 50.93 & 1.80 & 12.87 & 0.53 & 17.77 & 22.93 \\
\hline LD13-08470 & 44.00 & 113.52 & 18.87 & 44.80 & 3.60 & 24.33 & 3.23 & 0.30 & 38.60 & 1.57 & 10.23 & 0.50 & 19.73 & 14.67 \\
\hline LD13-03483 & 43.00 & 116.22 & 15.27 & 35.73 & 3.57 & 19.87 & 3.00 & 0.30 & 35.33 & 1.80 & 13.53 & 0.33 & 19.23 & 11.77 \\
\hline LD13-08466 & 42.33 & 128.17 & 15.07 & 40.87 & 4.00 & 26.93 & 3.00 & 0.30 & 45.87 & 1.70 & 9.70 & 0.57 & 18.60 & 19.43 \\
\hline LD13-06216 & 46.00 & 116.20 & 14.20 & 43.80 & 3.90 & 19.87 & 3.03 & 0.30 & 33.20 & 1.70 & 12.37 & 0.47 & 19.93 & 17.33 \\
\hline LD10-10198 & 42.00 & 113.53 & 13.53 & 37.93 & 3.60 & 23.87 & 3.03 & 0.30 & 43.20 & 1.83 & 14.00 & 0.43 & 16.70 & 19.23 \\
\hline LD13-07022 & 45.33 & 113.54 & 14.53 & 47.53 & 3.70 & 23.47 & 3.03 & 0.30 & 41.87 & 1.80 & 10.57 & 0.57 & 19.23 & 19.73 \\
\hline F6 LG06-5920 x LG04-6000 & 46.33 & 113.18 & 17.60 & 41.40 & 5.23 & 23.73 & 2.80 & 0.30 & 42.07 & 1.77 & 11.73 & 0.50 & 17.50 & 20.23 \\
\hline LG04-4468 x U02-242055 & 44.33 & 113.67 & 15.07 & 51.13 & 5.03 & 29.27 & 2.97 & 0.30 & 54.27 & 1.90 & 14.13 & 0.40 & 18.50 & 16.20 \\
\hline LG04-5993 x LG04-5196 & 46.00 & 116.29 & 16.53 & 44.53 & 3.57 & 19.73 & 3.40 & 0.37 & 33.53 & 1.70 & 15.80 & 0.43 & 21.90 & 16.73 \\
\hline F6 LG04-4717 x LG05-4292 & 44.33 & 112.62 & 13.60 & 43.47 & 4.67 & 20.87 & 2.97 & 0.30 & 38.27 & 1.83 & 11.07 & 0.47 & 18.03 & 15.03 \\
\hline PI200466 & 52.00 & 137.21 & 16.47 & 64.33 & 5.83 & 24.73 & 3.40 & 0.30 & 42.67 & 1.73 & 23.20 & 0.43 & 21.03 & 20.60 \\
\hline PI587905 & 60.33 & 140.09 & 28.20 & 62.93 & 4.70 & 34.20 & 2.97 & 0.30 & 62.33 & 1.83 & 23.53 & 0.40 & 15.73 & 28.90 \\
\hline PI416778 & 48.67 & 136.99 & 13.73 & 37.07 & 3.33 & 25.40 & 3.40 & 0.37 & 28.73 & 1.13 & 20.27 & 0.20 & 23.63 & 8.43 \\
\hline PI459025B & 64.00 & 128.15 & 19.73 & 68.27 & 5.63 & 28.67 & 4.27 & 0.37 & 53.20 & 1.87 & 19.63 & 0.43 & 24.53 & 26.33 \\
\hline PI594149 & 52.33 & 124.98 & 24.80 & 58.87 & 3.63 & 24.00 & 3.90 & 0.40 & 42.60 & 1.80 & 25.73 & 0.37 & 28.60 & 26.10 \\
\hline PI417126 & 50.33 & 132.76 & 14.33 & 48.40 & 4.10 & 29.47 & 3.53 & 0.40 & 51.47 & 1.70 & 29.57 & 0.20 & 25.00 & 17.90 \\
\hline $\begin{array}{l}\text { PI507005 } \\
\end{array}$ & 58.33 & 120.36 & 15.40 & 63.00 & 4.63 & 25.33 & 3.77 & 0.30 & 41.87 & 1.63 & 23.10 & 0.33 & 20.90 & 16.33 \\
\hline PI615437 & 71.67 & 141.49 & 23.07 & 84.07 & 5.77 & 32.67 & 3.43 & 0.27 & 56.07 & 1.73 & 23.53 & 0.30 & 14.30 & 14.53 \\
\hline PI628932 & 61.00 & 134.79 & 23.13 & 70.87 & 5.97 & 27.93 & 3.03 & 0.30 & 36.40 & 1.27 & 23.90 & 0.30 & 21.13 & 17.17 \\
\hline PI462312 & 59.67 & 134.68 & 21.60 & 73.27 & 6.33 & 28.93 & 3.30 & 0.30 & 44.93 & 1.60 & 17.90 & 0.27 & 19.50 & 17.60 \\
\hline $\begin{array}{l}\text { PI605773 } \\
\end{array}$ & 67.67 & 139.57 & 25.60 & 85.13 & 5.63 & 26.13 & 3.97 & 0.30 & 43.07 & 1.67 & 21.83 & 0.23 & 17.63 & 12.07 \\
\hline PI605854B & 71.67 & 136.75 & 22.07 & 82.33 & 5.17 & 30.33 & 3.27 & 0.27 & 53.47 & 1.77 & 13.83 & 0.67 & 14.63 & 16.63 \\
\hline PI594767A & 69.33 & 134.47 & 34.20 & 70.60 & 4.50 & 31.67 & 2.80 & 0.27 & 51.07 & 1.63 & 16.63 & 0.30 & 13.97 & 16.53 \\
\hline PI416873B & 50.67 & 106.28 & 15.80 & 62.80 & 5.23 & 25.40 & 3.90 & 0.30 & 43.40 & 1.70 & 19.90 & 0.43 & 19.73 & 21.93 \\
\hline PI567180 & 60.67 & 138.97 & 18.20 & 74.47 & 5.57 & 17.07 & 3.80 & 0.30 & 39.40 & 2.30 & 18.73 & 0.27 & 17.27 & 11.80 \\
\hline PI423960B & 60.00 & 131.41 & 18.80 & 72.40 & 5.80 & 26.80 & 3.17 & 0.30 & 40.47 & 1.53 & 24.90 & 0.27 & 20.13 & 19.50 \\
\hline PI635999 & 73.67 & 138.55 & 21.80 & 91.73 & 6.17 & 29.33 & 3.40 & 0.30 & 49.40 & 1.70 & 37.97 & 0.27 & 20.53 & 20.13 \\
\hline PI605865B & 64.67 & 138.25 & 23.87 & 73.87 & 4.97 & 27.20 & 3.37 & 0.30 & 39.13 & 1.47 & 21.40 & 0.27 & 15.67 & 18.03 \\
\hline PI423960A & 60.00 & 129.64 & 19.53 & 82.67 & 5.70 & 34.87 & 3.23 & 0.30 & 52.13 & 1.50 & 21.20 & 0.37 & 17.00 & 19.00 \\
\hline Afgat & 55.33 & 130.99 & 26.80 & 83.87 & 6.10 & 29.20 & 4.17 & 0.30 & 52.60 & 1.77 & 17.23 & 0.40 & 14.20 & 15.83 \\
\hline Nyala & 63.67 & 132.08 & 24.60 & 76.80 & 4.93 & 21.80 & 3.77 & 0.30 & 39.27 & 1.80 & 15.93 & 0.37 & 16.87 & 20.00 \\
\hline Nova & 49.00 & 116.77 & 22.00 & 72.67 & 4.77 & 35.60 & 3.37 & 0.20 & 73.53 & 2.10 & 15.90 & 0.43 & 12.37 & 18.33 \\
\hline Clark $63 \mathrm{~K}$ & 73.00 & 130.12 & 26.00 & 84.27 & 5.30 & 32.87 & 3.63 & 0.30 & 55.47 & 1.70 & 17.27 & 0.30 & 13.57 & 12.37 \\
\hline
\end{tabular}




\section{REFERENCES}

Abush Tesfaye.2012. Genetic analysis of quantitative traits in Soybean (Glycine max L. Merril) under low and high phosphorus conditions. Ph.D Thesis. University of KwaZulu-Natal, Pietermaritzburg. South Africa.184 pp.

Aditya J.P., Bhartiya P. \& Bhartiya A. 2011.Genetic variability, heritability and character association for yield and component characters in soybean (Glycine $\max (\mathrm{L}$.) Merrill). Journal of Central European Agriculture.12:2734.

Agdew Bekele1, GetintAlemaw\&Habtamu Zeleke.2012. Genetic divergence among soybean (Glycine max (L) Merrill) introductions in Ethiopia based on agronomic traits. Journal of Biology, Agriculture and Health care. 2(6):6-12.

DeresseHunde .2017.Genetic variability, heritability and genetic advances of soybean (Glycine max (L.) Merrill) varieties grown at Bako Tibe in Western Ethiopia. Asian Journal of Plant Science and Research. 7(5):20-26.

Deshmukh S.N., Basu M.S. \& Reddy P.S.1986. Genetic variability, character association and path coefficients of quantitative traits in Virginia bunch varieties of groundnut. Indian Journal of Agricultural Sciences.4(9):1-4.

Dewey D.R. \& Lu K. 1959. A correlation and path-coefficient analysis of components of crested wheatgrass seed production. Agronomy journal.51(9):.515-518.

Gomez, A.G. \& A. A. Gomez. 1984. Statistical procedure for Agricultural research, Jhon Wiley and son Inc., New York.680 pp.

Johnson. H.W., Robinson. H.F. \& Comstock R.E. 1955. Estimates of genetic and environmental variability in soybeans. Agronomy journal. 47(7):314-318.

Malik M.F.A., Ashraf M.U., Qureshi A.S. \& Ghafoor A. 2007.Assessment of genetic variability, correlation and path analyses for yield and its components in soybean. Pakistan Journal of Botany. 39(2) 394:405.

Pawar KK., Rangare N.R. \& Singh A.K. 2014. Evaluation of soybean (Glycine maxL.)germplasm for some important morphological traits using multivariate analysis. Indian Journal of Agricultural Sciences 84(4): 531-543

Preeti P., Rajeev S., Sunil K. N. \&IshuKute. 2018. Correlation analysis for seed yield and its attributing traits in soybean (Glycine max L. Merrill). Int.J.Curr.Microbiol.App.Sci. 7(04): 2034-2040.

Ramteke R., Kumar V., Murlidharan V., Agarwal DK.2010. Study on genetic diversity and traits interrelationship among released soybean varieties of India (Glycine max L. Merrill). .Electronic Journal of Plant Breeding.1: $1483-1487$

Reni Y. P. \&RaoY. K. 2013. Genetic variability in soybean [Glycine max (L) Merrill]. International Journal of Plant, Animal and Environmental Sciences. 3(4):35-38.

Robinson H.F., Comstock R.E. \& Harvey P.H.1949. Estimates of heritability and the degree of dominance in corn. Agronomy Journal.

Shankar k. 2014. Genetic diversity studies in soybean [glycine max (1.) Merrill] for various seed \& yield contributing characters. Ph.D Thesis acharya ngranga agricultural university rajendranagar, hyderabad) $127 \mathrm{pp}$.

Sharma J.R. (1998). Statistical and biometrical techniques in plant breeding. New Age International.

Singh M. \&Ceccarelli S. 1996. Estimation of heritability of crop traits from variety trial data. ICARDA.

Sivasubramanian S. \& Menon M. 1973. Heterosis and inbreeding depression in rice. Madras Agric. J 5:60:1139.

Sultana S., Rahman L., \& Habib S. H.2005. Genetic variability correlation and path analysis in soybean (Glycine $\max ($ L.) Merrill).International. Journal of Sustainable Agricultural Technology.1(5): 16-20.

Sureshrao, S.S., Singh, V.J., Gampala, S. \&Rangare, N.R., 2014. Assessment of genetic variability of the main yield related characters in soybean. International Journal of Food, Agriculture and Veterinary Sciences.4(2):69-74

Yadav S.K., Pandey P., Kumar B. \& Suresh B.G. 2011. Improvement in Rice (Oryza sativa) .Pakistan Journal of Biological Sciences.14(9):540-545.

Wanderi S.W., Githiri S.M., Sibiya J. \&Muthomi J.2013. Assessment of genetic variability among Kenyan soybean (Glycine max (L.)Merill) accessions and other introductions. In Joint Proceedings of the 27th Soil Science Society of East Africa and the 6th African Soil Science Society Conference.

ZinawDilnesaw., Seleten Abadi., FitsumMerkeb., NeguseDechassa. \&Habtamu Zelek.2013. Genetic variability and character association of twenty soybean (Glycine Max L. Merrill) genotypes for biological nitrogen fixation and related traits in Pawe District Metekel Zone Northwestern Ethiopia. Global Advanced Research Journal of Food Science and Technology. 3(5) :135-140. 